\title{
Quantification of Urban Patterns and Processes through Space and Time Using Remote Sensing Data: A Comparative Study between Three Saudi Arabian Cities
}

\author{
Abdullah F. Alqurashi
}

check for

updates

Citation: Alqurashi, A.F.

Quantification of Urban Patterns and Processes through Space and Time

Using Remote Sensing Data: A

Comparative Study between Three Saudi Arabian Cities. Sustainability 2021, 13, 12615. https://doi.org/ $10.3390 /$ su132212615

Academic Editor: Mohammad Valipour

Received: 20 October 2021

Accepted: 10 November 2021

Published: 15 November 2021

Publisher's Note: MDPI stays neutral with regard to jurisdictional claims in published maps and institutional affiliations.

Copyright: (C) 2021 by the author. Licensee MDPI, Basel, Switzerland. This article is an open access article distributed under the terms and conditions of the Creative Commons Attribution (CC BY) license (https:/ / creativecommons.org/licenses/by/ $4.0 /)$.
Department of Geography, Umm Al-Qura University, Makkah 21955, Saudi Arabia; afalqurashi@uqu.edu.sa

\begin{abstract}
Saudi Arabia has developed rapidly over the last five decades in the wake of an extensive development programme implemented by the government throughout the entire country. Several previous studies have measured the extent and rate of urbanization in Saudi Arabian cities, but most of this research used only remote sensing data or a single index to explain urban growth patterns. This study used satellite data and a set of landscape metrics to quantify the spatiotemporal urban growth patterns and processes in three Saudi Arabian cities-Riyadh, Jeddah and Makkah. First, Landsat images were collected and classified for the years 1985, 1990, 2000, 2007, 2014 and 2020. Classification was carried out through an object-based image analysis (OBIA) to map the extent of urbanization. The classified maps were then used to compute seven landscape metrics to determine the spatial configuration of urban areas. The spatial metrics were calculated for the entire landscape and across buffer zones that were delineated from the urban core centre of each city. The overall accuracies were $>94 \%$ for all the classified maps. The spatiotemporal results indicated that all three cities have experienced significant urban growth during the last four decades. Urban patterns in Jeddah were more dispersed than in Riyadh, which showed aggregated patterns (especially in recent years), while urban growth in Makkah tended to be more fragmented. The urban form in Riyadh was relatively simple, while a complex form was associated with Makkah and Jeddah. Understanding the rates, patterns, processes and trajectories of changes to urban land use is essential for various decision-making processes.
\end{abstract}

Keywords: urban growth; urban-growth patterns; urban-growth processes; Landsat; landscape metrics; Saudi Arabia

\section{Introduction}

Urbanization results from an expansion of the population and the conversion of rural areas to urban areas [1,2]. Worldwide, the population has increased rapidly from around 200 million in 1900 to 7.7 billion in 2019 [3]. This figure is expected to grow to 8.5 billion in 2030, 9.7 billion in 2050 and 10.9 billion in 2100 [3]. Half of this growth has occurred in urban areas [4,5], and most of the net increase has been in developing countries [6]. As a result of this growth, the size of cities has increased substantially in recent years, [7] leading to a significant modification to landscape patterns [8] and alterations to regional and global ecosystems $[9,10]$. Measuring the dynamics of urban land cover and quantifying its spatial patterns can provide vital information for planners and land managers to ensure sustainable development for future growth.

Urbanization is influenced by several socioeconomic and political factors, such as population, gross domestic product (GDP), transportation, land use policy and urban planning [11,12]. These factors can play an important role in changing the form and spatial patterns of an urban area. The development policy in Saudi Arabia has contributed substantially to the expansion of urban cover. During the 1970s, the government implemented an extensive development programme throughout the entire country that was financed by the 
huge oil revenues at that time $[13,14]$. Among the policies adopted to enhance the development process was the provision of no-interest loans to both the public and private sectors, which led to extensive development throughout the country [15-17]. This development resulted in an expansion of urban cover that, in turn, produced unprecedented environmental changes such as in hydrological processes, climatic systems, landscape ecology and various aspects of land cover patterns. With such rapid and dynamic changes, adequate methods to measure urban areas through space and time were required to understand their spatial and temporal patterns as well as their spatial processes.

Essential information on spatiotemporal changes of urban cover can be accurately obtained from remotely sensed data. Remote sensing can provide valuable information on urban expansion and other land use and cover types over time, either at a global or local scale $[18,19]$. The availability of long-term and systematic remotely sensed data (e.g., Landsat images) has encouraged scientists to analyse various land cover features [20], including urban changes, using time series-based methods. The remote sensing data may be coupled with advanced geospatial methods that effectively extract urban cover information from satellite data. Typically, these methods rely on two types of image recognition-pixel and object-based image analysis. Pixel-based image analysis methods have been widely used to extract urban cover areas (e.g., [21,22]). Object-based image analysis has attracted much attention recently from researchers in image classification (e.g., $[23,24])$, due to its ability to include contextual information in the classification that can improve the accuracy in the classification $[25,26]$ of urban land cover.

In addition to the spatial extent and the growth rate of urban cover that could be measured by remotely sensed data, a further analysis of the structural changes and the process of urban form is required to understand the spatiotemporal nature of urban growth. The increase in urban areas over time resulted from demographic and economic changes as well as planning policies. These dynamic changes may create urban agglomerations and generate a spatial pattern that appears somewhat irregular or is distributed in a nonuniform way [27]. Therefore, the spatial form of urban growth can be measured in terms of aggregation, compaction and isolation [28], which explain the structural changes and the spatial patterns of urban growth over time. Quantifying the structural changes and the spatial patterns of urban areas and other land cover types can be achieved by the use of landscape metrics $[29,30]$. Integrating remotely sensed data with landscape metrics is valuable in clarifying the spatial processes of urban growth and to explain its patterns.

Several studies in the past have identified the spatiotemporal structure of urban growth using remotely sensed data and landscape metrics. Regarding compaction, dispersion, fragmentation and extensive growth, Schneider and Woodcock [31] examined the similarities and differences in the urban form and growth among 25 mid-sized cities worldwide using remotely sensed data and landscape metrics. Similarly, Aguilera et al. [28] quantified three urban growth processes (aggregation, compaction and dispersion) and four patterns (aggregated, linear, leapfrogging and nodal) based on three future scenarios. The diffusion and coalescence processes of urban growth have been identified using landscape metrics by Dietzel et al. [32] and Liu et al. [8]. In terms of the type of analysis used to measure urban patterns, Seto and Fragkias [4] as well as Dietzel et al. [32] calculated the landscape metrics using concentric rings that were drawn from the city centre to capture the variations of urban growth among the buffer zones. The findings of these studies emphasise the importance of measuring urban patterns and processes and confirmed that landscape metrics can be effectively used to quantify the spatial characteristics of urban growth.

In Saudi Arabia, however, most previous research measured the spatiotemporal extent of urban expansion and growth rate using only satellite data (e.g., $[14,17,33,34])$, or it was based on the transportation and population density indices [35]. Only Rahman [36] measured urban sprawl in Al-Khobar, Saudi Arabia, using the Shannon relative entropy index during 1990, 2001 and 2013. This study found the city dispersing near the outside and towards its neighbouring cities. However, different subsets of spatial metrics among 
different cities could provide a logical explanation for urban growth patterns rather than a single index. Therefore, this research aims to analyse the spatiotemporal structure of the urban form and pattern among the most rapidly urbanized cities in Saudi Arabia-Riyadh, Jeddah and Makkah. First, it aims to quantify the spatial extent of urban cover between 1985 and 2020 using Landsat images; second, it seeks to identify the growth processes and spatial patterns of urban cover in these cities. Two questions are addressed: How does urban growth change over space and time? How do urban patterns and processes vary from city to city? Understanding urban growth patterns is essential for better planning and sustainable development.

\section{Study Area}

The study area includes three cities in Saudi Arabia-Riyadh, Jeddah and Makkah (Figure 1). Riyadh is the capital city of Saudi Arabia and is situated in the central part of the country on the large Najd plateau. It is the largest city in Saudi Arabia with a population of around seven million. Jeddah is the second largest city in the country. It is in the western part of Saudi Arabia and is considered the largest seaport on the Red Sea coast. The city has a population of more than four million and is viewed nationally as an important commercial hub. Makkah, the third city in this study, is in the central part of the Makkah region, about $70 \mathrm{~km}$ inland from Jeddah. Makkah is the holy place of the Muslim community and receives more than three million visitors annually to embrace the rituals of the Hajj pilgrimage [14]. The normal population of Makkah is around two million. The boundary of each city was selected based on the current urban limits, which included the municipal boundary for each city. All urban areas and their surroundings rural areas are included in the city boundary (Figure 1).

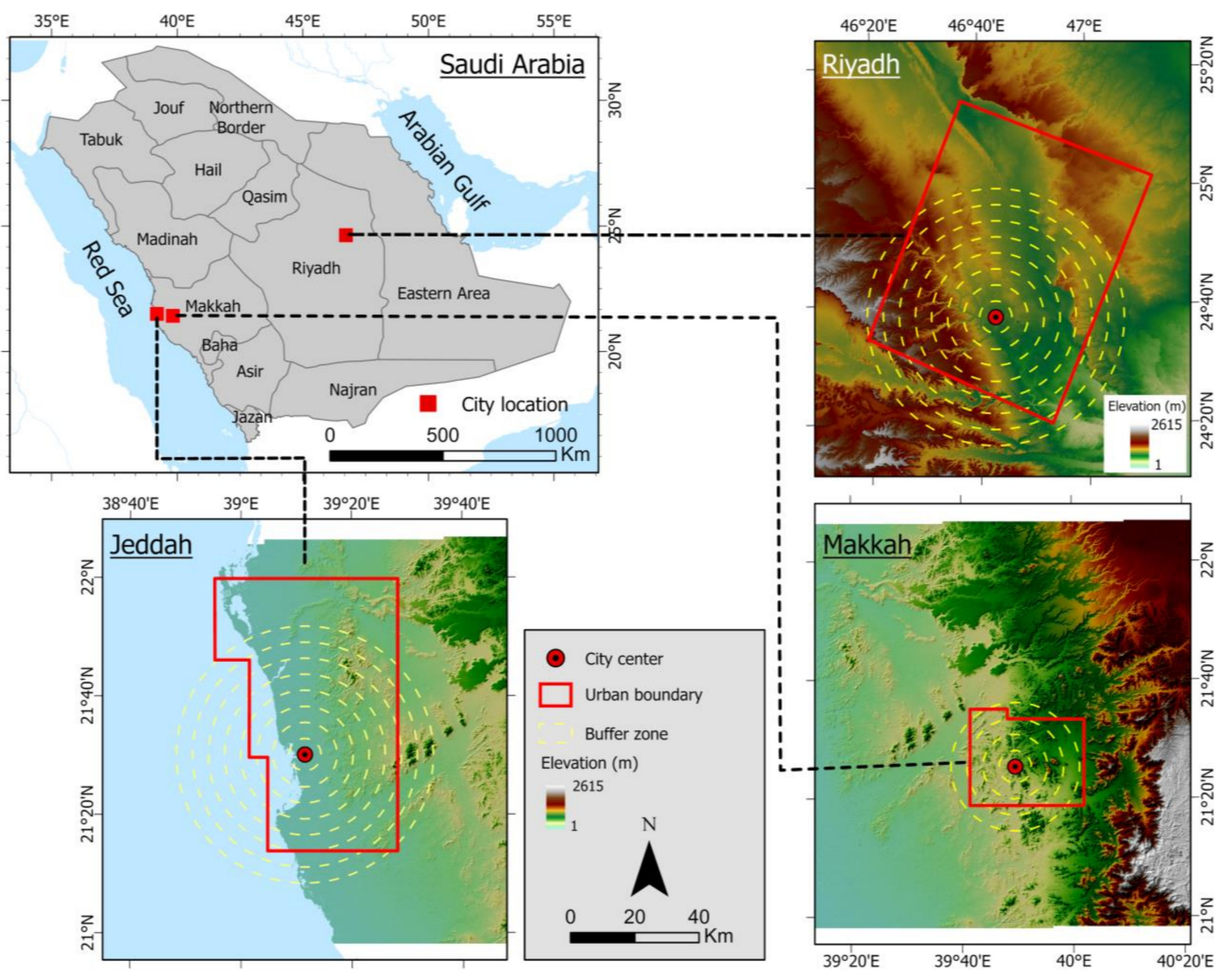

Figure 1. The location of the study areas in Saudi Arabia. 
All three cities have experienced rapid urbanization during the last five decades due to an increase in both internal and external migration [37]. Each city has certain characteristics that make it attractive to immigrants. Job opportunities in the governmental sectors and educational benefits in Riyadh, and economic advantages in Jeddah, have resulted in increased migration from rural areas to these cities. Makkah also has witnessed an increase in immigration in recent years with many pilgrims deciding to remain in the city following their pilgrimage [38] due to economic or religious reasons. These factors, together with natural growth, have accelerated population growth in these cities. The increase in population has resulted in massive urban growth and further complexity in the structure of the cities. Understanding urban patterns and processes is essential for managing the current urbanization and for securing sustainable development for future growth in these cities.

\section{Materials and Methods}

\subsection{Data and Pre-Processing}

A total of 24 Landsat thematic mapper images (TM), enhanced thematic mapper plus $(\mathrm{ETM}+)$ and operational land imager (OLI) images were collected from the United States Geological Survey (USGS) Global Visualization (GloVis) site for the three cities. The images were acquired between spring and summer (from March to November), except for the 1985 image of Riyadh (path 165-166 and row 43), which was collected during winter (January) (Table 1). As a level-1 product, all images were already georeferenced and rectified to WGS 1984 UTM Zone 37N for Jeddah and Makkah and WGS 1984 UTM Zone 38N for Riyadh. However, the TM image (path 165 and row 43) of Riyadh was not correctly georeferenced. An automatic image-to-image registration approach was adopted using the OLI image of a similar path and row as a base image and the TM image was employed as a wrap image. Finally, subset settings were applied to all images, including all the urban boundaries across the three cities. The entire pre-processing steps were carried out using ENVI 5.4 software.

Table 1. Information of Landsat data used in this research.

\begin{tabular}{cccc}
\hline City & Sensor & Path/Row & Date \\
\hline \multirow{5}{*}{ Riyadh } & TM & & $\begin{array}{c}\text { (13-20 January 1985), (14-15 August 1990), } \\
\text { (18-25 August 2000) } \\
\text { (20-29 July 2007) }\end{array}$ \\
& ETM+ & 165-166/43 & (9-16 August 2014), (2-9 March 2020) \\
\hline \multirow{3}{*}{ Jeddah } & OLI & & (9 June 1985), (11 September 1990) \\
& TM & & (1 November 2000), (17 August 2007) \\
& OLI & $170 / 45$ & (29 September 2014), (24 May 2020) \\
\hline \multirow{3}{*}{ Makkah } & TM & & (6 August 2000), (5 August 2007) \\
& ETM+ & 169/45 & (5 August 2014), (15 April 2020)
\end{tabular}

\subsection{Image Classification}

An object-based image analysis (OBIA) approach was used to create urban cover during the 1985, 1990, 2000, 2007, 2014 and 2020 periods. The process of OBIA included both image segmentation and classification. The analysis of image segmentation and classification was carried out using eCognition Developer 9.0.1 software. Image segmentation is the initial step of OBIA, in which the remotely sensed image is divided into discrete regions or objects that are homogeneous, based on their colour, texture, spatial and spectral characteristics [39,40]. The multi-resolution algorithm was applied to create objects that delineated classes. The scale parameter was set at 5 , while shape and compactness were adjusted to 0.1 and 0.8 , respectively.

The classification of segmented objects was applied first to the 1985 image using the defined rules and threshold values. The classification was divided into four land cover 
classes-water (W), vegetation cover (VC), urban area (UA) and bare soil (BS)-in the class hierarchy. Several feature sets, including spectral patterns of Landsat TM bands Normalised Difference Vegetation Index (NDVI), Normalised Difference Water Index (NDWI) and brightness (the mean of six TM bands) were used in the classification analysis. The threshold values of the selected feature sets were defined based on previous studies [26,41-43]. Then, the classified image of 1985 was converted into a vector layer and used as a thematic layer (reference) to classify the 1990 image (Figure 2). The objects with no change (NC) for each land cover type were assigned as ' $\mathrm{NC}^{\prime}$ ' followed by the name of the class. For example, if an object classified as water (W) in 1985 did not change in 1990, the object assigned in 1990 was NC-W, and so on. The changed objects between 1985 and 1990 were classified according to the new state of 1990. For example, objects classified as vegetation cover (VC) in 1985 and changed to bare soil (BS) in 1990 were then assigned as VC-to-BS. At the end of these processes, 13 subclasses were created in which 4 subclasses were assigned to urban areas and 3 subclasses were assigned to other land cover types. Subsequently, the subclasses were merged into the four assigned classes, which created the final classification of the 1990 image. By following similar analytical steps to the 1990 classification processes, the 2000, 2007, 2014 and 2020 images were classified and produced for all three cities [37,44]. Finally, the other three land cover categories of W, VC and BS were reclassified as non-urban areas, since the aim of this paper is to analyse urban patterns and processes. Therefore, the final classification results presented two classes, including urban and non-urban areas, which were then used for the spatial metrics analysis (Figure 2).

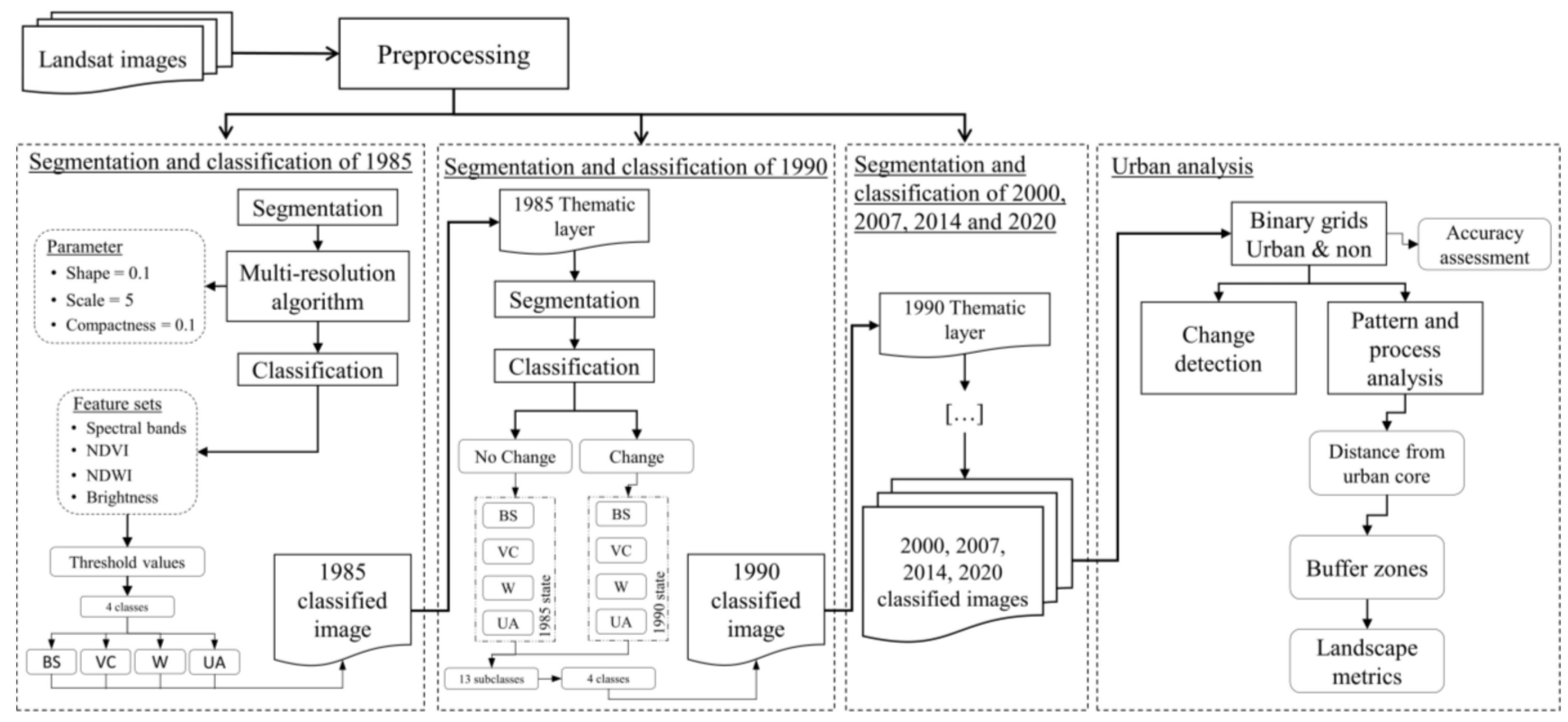

Figure 2. Flowchart of the research methodology.

\subsection{Accuracy Assessment}

The accuracy assessment was conducted using a stratified random sampling method to create the reference points of the 1985, 1990, 2000, 2007, 2014 and 2020 classified images for each city. As the extent of each city was different, the size of the sample points varied among the study areas. For large cities (Riyadh and Jeddah), 800, 900, 1000, 1200, 1500 and 1600 sample points were identified for 1985, 1990, 2000, 2007, 2014 and 2020, respectively. For Makkah (which is a relatively small area), 450, 500, 600, 700, 800 and 900 sample points were selected for 1985, 1990, 2000, 2007, 2014 and 2020, respectively. A confusion matrix, calculated between the classified images and the ground truth points, was created based on the same Landsat images using visual interpretation. The accuracy assessment was computed on two classes-urban and non-urban areas (Figure 2). 


\subsection{Spatial Urban Metrics}

The classified maps of urban areas were then used to calculate landscape metrics for each period between 1985 and 2020. Since a wide range of metrics was developed [29,45], a set of metrics was selected based on previous research [4,32,46-49]. Therefore, seven metrics were computed, which included the percentage of landscape (PLAND) patch density (PD), edge density (ED), area weighted mean patch fractal dimension (FRAC_AM), mean of Euclidean nearest-neighbour distance (ENN_MN), standard deviation of Euclidean nearest-neighbour distance (ENN_SD), number of patches (NP) and contagion (CONTAG). Table 2 lists the selected metrics and their information, which were adopted from McGarigal et al. [45]. Since this study aims to identify the patterns and processes of urban growth, the calculation of landscape metrics was performed only on a class level [45]. The landscape metrics were calculated by using an open-source $\mathrm{R}$ tool called landscapemetrics that was developed by Hesselbarth et al. [50].

Table 2. Urban landscape metrics used in this research. Information adopted from McGarigal et al. [45].

\begin{tabular}{|c|c|c|c|}
\hline Metric (Abbreviation) & Description & Equation & \\
\hline $\begin{array}{l}\text { Percent of landscape } \\
\text { (PLAND) }\end{array}$ & $\begin{array}{c}\text { A composition metric that } \\
\text { measures the percentage of } \\
\text { the landscape belonging to } \\
\text { urban area. }\end{array}$ & $P L A N D=P_{i}=\frac{\sum_{j=1}^{n} a_{i j}}{A}(100)$ & $\begin{array}{l}\qquad P_{i}=\text { proportion of the } \\
\text { landscape occupied by patch } \\
\text { type (class) } i ; a_{i j}=\text { area }\left(\mathrm{m}^{2}\right) \text { of } \\
\text { patch } i j ; \mathrm{A}=\text { Area of the total } \\
\text { landscape }\left(\mathrm{m}^{2}\right) .\end{array}$ \\
\hline Patch density (PD) & $\begin{array}{l}\text { An aggregation metric that } \\
\text { measures the fragmentation of } \\
\text { urban landscape. }\end{array}$ & $P D=\frac{n_{i}}{A}(10,000)(100)$ & $\begin{array}{c}n_{i}=\text { number of patches in the } \\
\text { landscape of patch } \\
\text { type (class) } i .\end{array}$ \\
\hline Edge density (ED) & $\begin{array}{l}\text { Describes the configuration of } \\
\text { urban landscape. }\end{array}$ & $E D=\frac{\sum_{k=1}^{m} e_{i k}}{A}(10,000)$ & $\begin{array}{c}e_{i k}=\text { total length }(\mathrm{m}) \text { of edge } \\
\text { in landscape involving patch } \\
\text { type (class) } i \text {. }\end{array}$ \\
\hline $\begin{array}{l}\text { Area weighted mean patch } \\
\text { fractal dimension } \\
\text { (FRAC_AM) }\end{array}$ & $\begin{array}{l}\text { A shape metric that measures } \\
\text { the complexity of patches } \\
\text { based on a perimeter to area } \\
\text { ratio. Here, area weighting is } \\
\text { applied for each patch. }\end{array}$ & $F R A C=\frac{2 \ln \left(0.25 P_{i j}\right)}{\ln a_{i j}}$ & $P_{i j}=$ perimeter $(\mathrm{m})$ of patch $i j$. \\
\hline $\begin{array}{c}\text { Mean of Euclidean } \\
\text { nearest-neighbour distance } \\
\text { (ENN_MN) }\end{array}$ & $\begin{array}{c}\text { An aggregation metric that } \\
\text { summarises each class as the } \\
\text { mean of each patch belonging } \\
\text { to urban area. }\end{array}$ & $\begin{array}{c}\operatorname{ENN}_{M N}= \\
\operatorname{mean}\left(\operatorname{ENN}\left[\text { patch }_{i j}\right]\right)\end{array}$ & $\begin{array}{l}E N N\left[\text { patch }_{i j}\right]=\text { the Euclidean } \\
\text { nearest-neighbour distance of } \\
\text { patch } i j .\end{array}$ \\
\hline $\begin{array}{c}\text { Standard deviation of } \\
\text { Euclidean nearest-neighbour } \\
\text { distance (ENN_SD) }\end{array}$ & $\begin{array}{l}\text { An aggregation metric that } \\
\text { summarises each class as the } \\
\text { standard deviation of each } \\
\text { patch belonging to urban area. }\end{array}$ & $E N N_{S D}=s d\left(E N N\left[\right.\right.$ patch $\left.\left._{i j}\right]\right)$ & \\
\hline Number of patches (NP) & $\begin{array}{l}\text { An aggregation metric that } \\
\text { measures the fragmentation of } \\
\text { urban area. }\end{array}$ & $N P=n_{i}$ & \\
\hline Contagion (CONTAG) & $\begin{array}{l}\text { An aggregation metric that } \\
\text { describes the probability of } \\
\text { two random cells belonging to } \\
\text { the same class. }\end{array}$ & CONTAG $=1+\frac{\sum_{q=1}^{n_{a}} p_{q} \ln \left(p_{q}\right)}{2 \ln (t)}$ & $\begin{array}{l}P_{q}=\text { the adjacency table for all } \\
\text { classes divided by the sum of } \\
\text { the table; } t=\text { the number of } \\
\text { classes in the landscape. }\end{array}$ \\
\hline
\end{tabular}

\subsection{Analysis Framework}

The analysis framework for computing landscape metrics was based on the distance from the urban core centre, which was determined by using topographic maps for each city. Buffer rings were generated for each city with equal distance intervals of five kilometres from the urban core centre. The distance intervals of the buffer rings depended on the size of the city. Jeddah and Riyadh have the same distance intervals, while Makkah has 
different distance intervals. Unlike Makkah, both Riyadh and Jeddah have relatively the same spatial size and the urban cover exceeds the buffer of $40 \mathrm{~km}$ from the urban core centre, while in Makkah the urban cover exceeds the buffer of $20 \mathrm{~km}$. Thus, the comparison was made between Jeddah and Riyadh for each metric. Urban landscape metrics were calculated and presented for each buffer. The raster grid for each period was extracted, based on the distance from the urban core centre using the buffer rings. Therefore, eight grids for both Riyadh and Jeddah and four grids for Makkah were created and used to calculate the landscape metrics during each period from 5 to $40 \mathrm{~km}$ for the two cities and 5 to $20 \mathrm{~km}$ for Makkah. The distance greater than $40 \mathrm{~km}(>40)$ in Riyadh and Jeddah and greater than $20 \mathrm{~km} \mathrm{(>20)} \mathrm{in} \mathrm{Makkah} \mathrm{represented} \mathrm{the} \mathrm{entire} \mathrm{landscape.} \mathrm{The} \mathrm{entire} \mathrm{landscape}$ for each city was calculated individually.

\section{Results}

\subsection{Accuracy Assessment}

Table 3 shows the accuracy assessment of the classified images of Riyadh, Jeddah and Makkah for the 1985, 1990, 2000, 2007, 2014 and 2020 classifications. The confusion matrix was calculated on two classes-urban and non-urban areas. Producer's and user's accuracies of urban cover as well as overall accuracies and kappa coefficients were presented in terms of percentage. The results indicated high accuracy for all three cities.

Table 3. The accuracy assessment of urban land cover classification.

\begin{tabular}{|c|c|c|c|c|c|c|c|c|c|c|c|c|}
\hline \multirow{2}{*}{ Date } & \multicolumn{4}{|c|}{ Riyadh } & \multicolumn{4}{|c|}{ Jeddah } & \multicolumn{4}{|c|}{ Makkah } \\
\hline & Producer's & User's & Overall & Kappa & Producer's & User's & Overall & Kappa & Producer's & User's & Overall & Kappa \\
\hline 1985 & 92.7 & 96.2 & 97.8 & 0.93 & 88.1 & 98.0 & 97.1 & 0.91 & 88.9 & 93.5 & 96.9 & 0.89 \\
\hline 1990 & 88.7 & 96.1 & 96.8 & 0.90 & 90.8 & 95.4 & 96.9 & 0.91 & 95.9 & 92.1 & 97.0 & 0.92 \\
\hline 2000 & 96.4 & 93.9 & 97.8 & 0.94 & 93.3 & 95.6 & 97.7 & 0.93 & 97.1 & 94.3 & 98.0 & 0.94 \\
\hline 2007 & 97.7 & 90.8 & 96.9 & 0.92 & 94.4 & 94.0 & 97.3 & 0.92 & 95.1 & 97.2 & 98.0 & 0.95 \\
\hline 2014 & 96.9 & 95.4 & 97.7 & 0.94 & 94.1 & 90.7 & 96.5 & 0.90 & 97.2 & 92.7 & 96.8 & 0.93 \\
\hline 2020 & 97.8 & 92.9 & 96.8 & 0.93 & 94.9 & 86.2 & 94.5 & 0.86 & 96.9 & 94.0 & 96.7 & 0.93 \\
\hline
\end{tabular}

\subsection{Urban Spatiotemporal Change Detection}

A change detection analysis was applied for the five time periods (1985-1990, 1990-2000, 2000-2007, 2007-2014 and 2014-2020) for Riyadh, Jeddah and Makkah. Figure 3 shows the spatiotemporal change of urbanization between 1985 and 2020, and Table 4 lists the percentage of urban growth during the six time periods for each ring buffer from the urban core centre in Riyadh. The urban areas were clustered around the centre between 1985 and 1990 within $20 \mathrm{~km}$ only from the urban core (Figure 3A). During the 1990-2000 period, new patches were created, particularly in the north-eastern section (Figure 3B). Mainly, this development occurred alongside the road networks that contributed significantly to the urban growth in the city. However, most of the expansion in Riyadh occurred between 2000 and 2007, when urban cover increased by about $40 \%$. Growth occurred in nearly all directions after 2000. New developments in the north-east and north-west sectors indicated that urban areas were expanding toward the outskirts of the city. Like the 2000-2007 period, the expansion continued during 2007 to 2014 in the same direction, but to a lesser extent (about 18\%). However, the growth rate decreased sharply after 2014, with the rate of urbanization increasing by almost 9\% between 2014 and 2020 . 


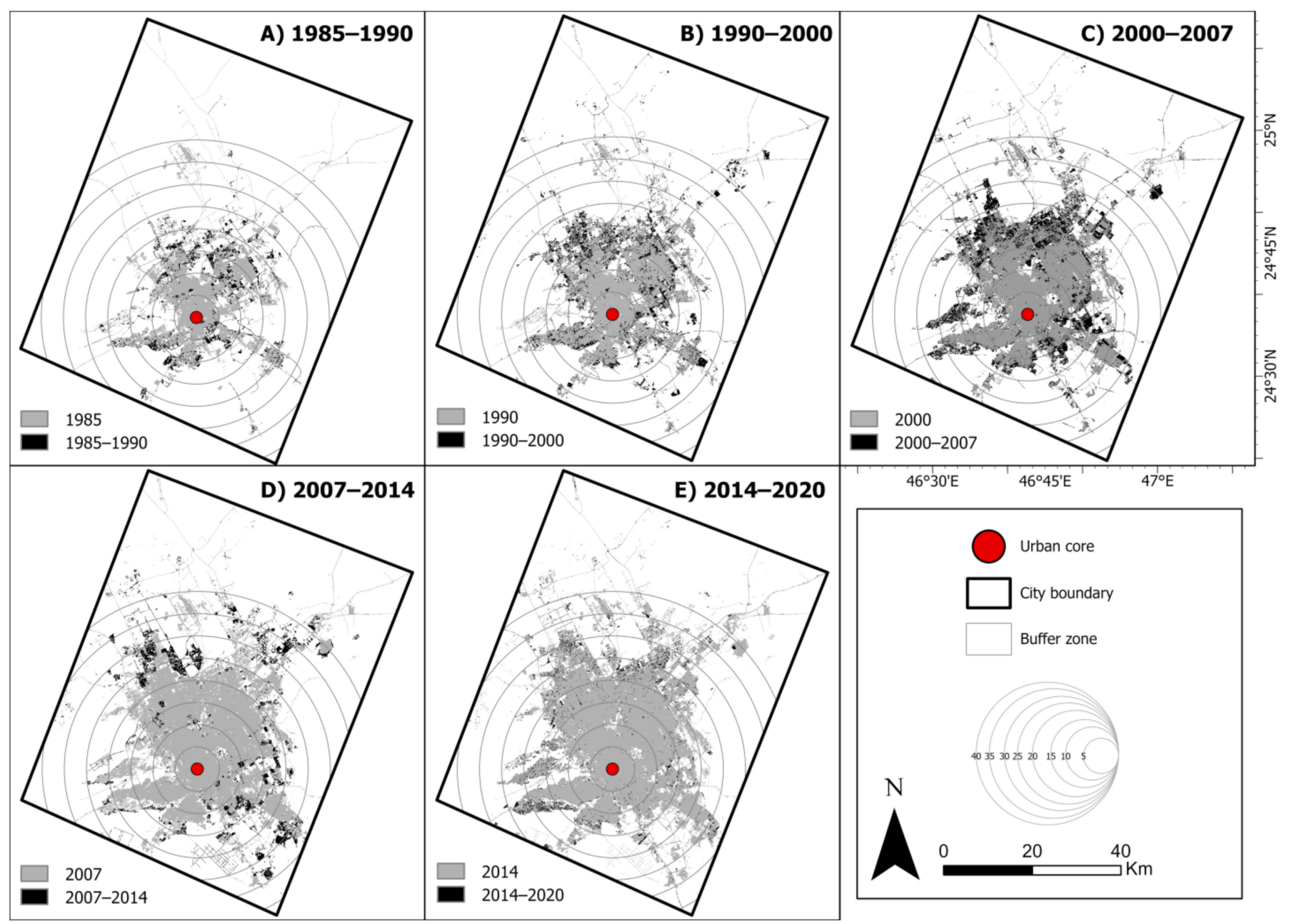

Figure 3. Urban expansion in Riyadh between 1985 and 2020: (A) 1985-1990; (B) 1990-2000; (C) 2000-2007; (D) 2007-2014; and (E) 2014-2020.

Table 4. The percentage increase in urban area in Riyadh for each period.

\begin{tabular}{cccccc}
\hline \multirow{2}{*}{ Distance (km) } & \multicolumn{5}{c}{ Increase (\%) } \\
\cline { 2 - 6 } & $\mathbf{1 9 8 5 - 1 9 9 0}$ & $\mathbf{1 9 9 0 - 2 0 0 0}$ & $\mathbf{2 0 0 0 - 2 0 0 7}$ & $\mathbf{2 0 0 7 - 2 0 1 4}$ & $\mathbf{2 0 1 4 - 2 0 2 0}$ \\
\hline 5 & 5.3 & 4.8 & 3.0 & 0.4 & 0.9 \\
10 & 10.9 & 14.7 & 10.8 & 2.9 & 2.0 \\
15 & 17.9 & 21.8 & 20.7 & 6.0 & 4.2 \\
20 & 20.5 & 29.3 & 26.9 & 7.8 & 5.5 \\
25 & 22.8 & 34.1 & 34.1 & 11.2 & 7.0 \\
30 & 23.0 & 34.9 & 37.7 & 14.6 & 8.1 \\
35 & 22.6 & 35.2 & 38.6 & 16.4 & 8.6 \\
40 & 22.2 & 35.3 & 39.1 & 17.4 & 8.7 \\
$*$ & 21.7 & 36.8 & 39.6 & 17.6 & 8.8 \\
\hline
\end{tabular}

${ }^{*}>40$ represents the whole city boundary.

Figure 4 shows the spatiotemporal change detection of urban cover in Jeddah between 1985 and 2020, and Table 5 represents the increased rate of urbanization for each period in percentage terms. The urban area in Jeddah increased significantly between 1985 and 2020, with most of the growth, about 41\%, occurring between 1990 and 2000. Unlike Riyadh, the 2000-2007 period witnessed a relatively low rate of urbanization, while the higher rate of urbanization was during 2007 to 2014, when growth nearly doubled. While the rate of urbanization during the 2014-2020 period was greater than the growth rate of Riyadh for 
the same period, the percentage increase in urbanization was low compared with other periods. The spatial distribution was controlled by the coastline in the western part of the city. Most of the expansion between 1985 and 2000 was within $25 \mathrm{~km}$ of the urban core centre and mostly occurred in the northern sector. After 2000, urban cover increased significantly in the north and exceeded the distance of $35 \mathrm{~km}$ from the urban core by 2014 . There was also a remarkable development in the south-east sector during that time.

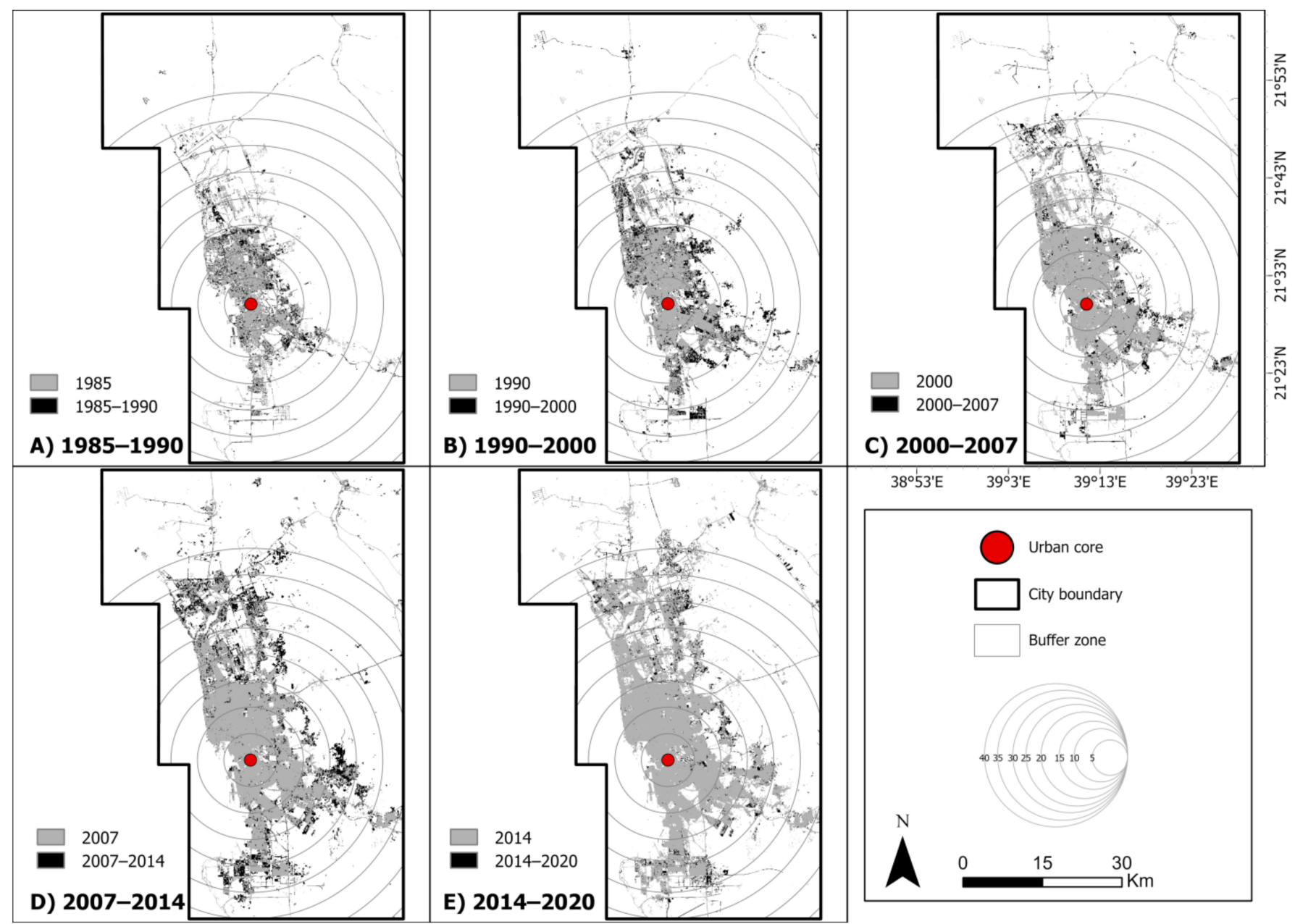

Figure 4. Urban expansion in Jeddah between 1985 and 2020: (A) 1985-1990; (B) 1990-2000; (C) 2000-2007; (D) 2007-2014; and (E) 2014-2020.

Table 5. The percentage increase in urban area in Jeddah for each period.

\begin{tabular}{cccccc}
\hline \multirow{2}{*}{ Distance $\mathbf{( k m )}$} & \multicolumn{5}{c}{ Increase (\%) } \\
\cline { 2 - 6 } & $\mathbf{1 9 8 5 - 1 9 9 0}$ & $\mathbf{1 9 9 0 - 2 0 0 0}$ & $\mathbf{2 0 0 0 - 2 0 0 7}$ & $\mathbf{2 0 0 7 - 2 0 1 4}$ & $\mathbf{2 0 1 4 - 2 0 2 0}$ \\
\hline 5 & 17.4 & 12.9 & 4.5 & 4.2 & 2.4 \\
10 & 26.8 & 18.3 & 6.4 & 5.3 & 2.1 \\
15 & 33.2 & 28.9 & 10.5 & 10.4 & 4.2 \\
20 & 33.9 & 33.2 & 13.0 & 21.0 & 6.9 \\
25 & 35.1 & 37.9 & 13.7 & 26.8 & 8.5 \\
30 & 35.7 & 39.7 & 15.5 & 29.9 & 9.6 \\
35 & 36.5 & 39.9 & 17.4 & 33.4 & 10.5 \\
40 & 36.7 & 39.9 & 18.0 & 35.6 & 11.7 \\
$*>40$ & 37.7 & 40.7 & 18.6 & 36.7 & 13.0 \\
\hline
\end{tabular}

${ }^{*}>40$ represents the whole city boundary. 
Change detection maps during the five time periods between 1985 and 2020 in Makkah are shown in Figure 5, and the percentage increase of the urban area for each period is shown in Table 6. In common with the other cities, Makkah has experienced rapid development during the last 35 years. Like Jeddah, most of its development, about $43 \%$, occurred between 2007 and 2014 (Table 6). The city also experienced a high rate of urbanization between $1990-2000$ and $1985-1990$, by $30 \%$ and $29 \%$, respectively. While Makkah is highly urbanized within its administrative boundary, urban growth was distributed mostly in the north-eastern sectors between 2007 and 2014 (Figure 5D). The development decreased significantly after 2014 and the rate of urbanization was very low in contrast with other periods.

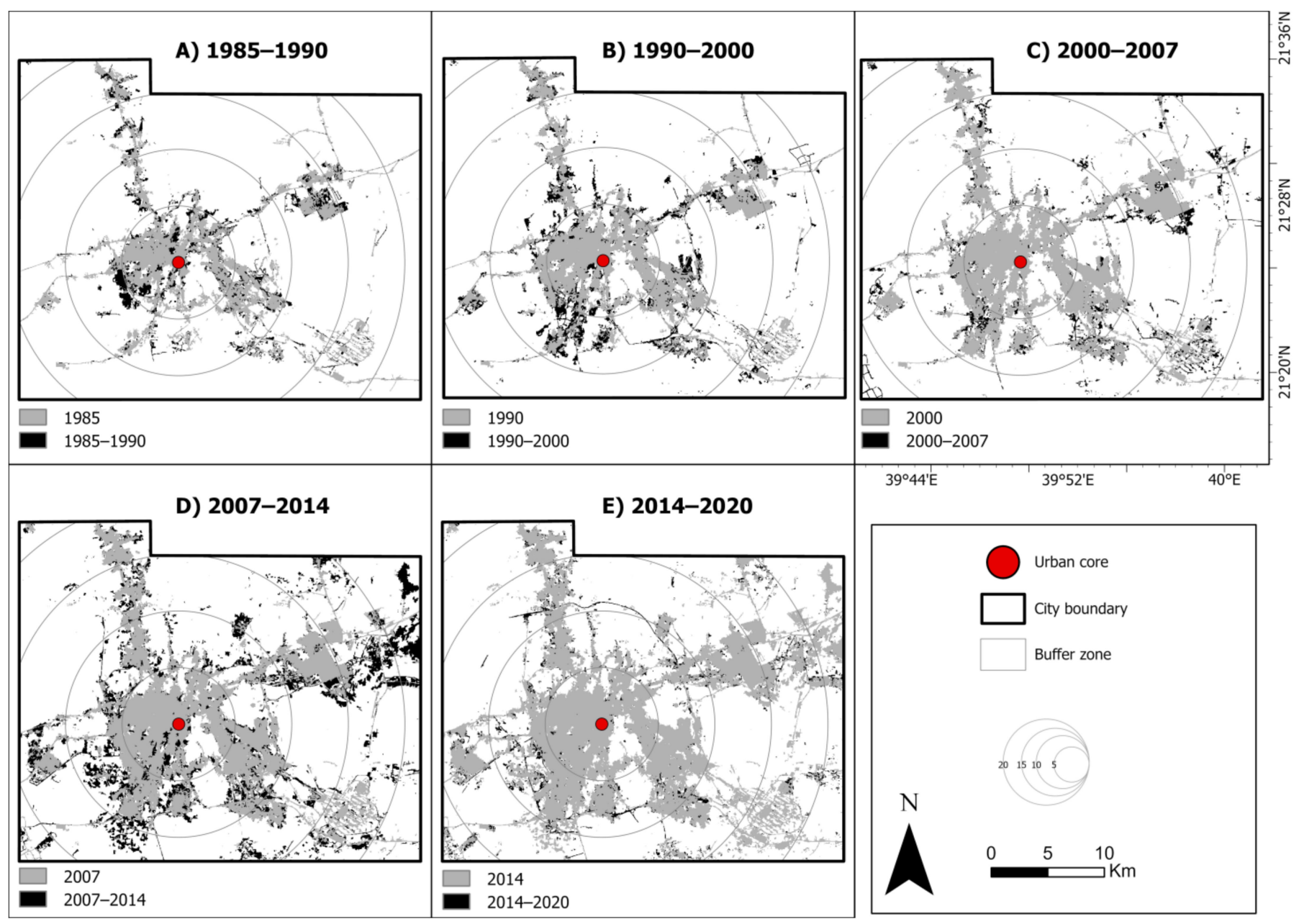

Figure 5. Urban expansion in Makkah between 1985 and 2020: (A) 1985-1990; (B) 1990-2000; (C) 2000-2007; (D) 2007-2014; and (E) 2014-2020.

Table 6. The percentage increase in urban area in Makkah for each period.

\begin{tabular}{cccccc}
\hline \multirow{2}{*}{ Distance (km) } & \multicolumn{5}{c}{ Increase (\%) } \\
\cline { 2 - 6 } & $\mathbf{1 9 8 5 - 1 9 9 0}$ & $\mathbf{1 9 9 0 - 2 0 0 0}$ & $\mathbf{2 0 0 0 - 2 0 0 7}$ & $\mathbf{2 0 0 7 - 2 0 1 4}$ & $\mathbf{2 0 1 4 - 2 0 2 0}$ \\
\hline 5 & 20.1 & 12.1 & 3.1 & 10.8 & 1.3 \\
10 & 28.0 & 30.9 & 10.4 & 27.1 & 6.5 \\
15 & 29.5 & 29.8 & 14.6 & 34.2 & 8.1 \\
20 & 29.0 & 29.7 & 17.1 & 39.1 & 8.3 \\
$*>20$ & 28.9 & 29.8 & 17.9 & 43.4 & 8.4 \\
\hline
\end{tabular}




\subsection{Urban Patterns and Processes}

Figure 6 shows a comparison analysis of the spatial metrics between Riyadh and Jeddah for each distance (5 to $40 \mathrm{~km}$ ) from the city centre, and Figure 7 presents a similar comparison for the entire landscape of both cities $(>40 \mathrm{~km})$. The percentage of urban cover increased between 1985 and 2020 in the entire landscape for both cities (Figure 7A). The PLAND values were greater than $85 \%$ in the central area of Riyadh (five kilometres distance from the urban centre), while the PLAND values in Jeddah were between $60 \%$ and 85\% between 1985 and 2020 (Figure 6A). The urban central area in Riyadh showed an increase in urbanization between 1985 and 2007, but it decreased after that. In Jeddah, however, the expansion in the central area continued to increase between 1985 and 2020. This indicates that the central part of Jeddah is more active than that of Riyadh, which had already been developed by 2007. It is also clear that the PLAND values decreased with increasing distance from the urban centre in both cities. However, it was observed that the curve direction changed slightly after 2000 in Riyadh, with the change observed within the $15-\mathrm{km}$ buffer zone. This indicates that the vacant lands within the buffer zone are likely to be occupied by urban areas. Therefore, the urban system in Riyadh is becoming more clustered.

The patch density (PD) in Figure 6B shows different results for the two cities. During the 1985 period, a significant number of patches was associated with Jeddah compared with other periods. PD peaked near the city core at 10 to $15 \mathrm{~km}$ of the buffer zone and declined thereafter. However, during this period the PD value was higher for the entire landscape. Similarly, the PD values increased near the city centre during 1990 and peaked at 10 to $15 \mathrm{~km}$, but the patch numbers declined for each distance at $20 \mathrm{~km}$. This suggested that the urban patches during 1985 were more fragmented than in other periods. The landscape was comprised of small and unconnected patches of urban land. The landscape of the urban area in Riyadh was less fragmented and relatively less patchy than in Jeddah. This indicates that urban patches in Jeddah, especially during 1985, were likely mixed with other land cover areas, while urban areas dominated the landscape in Riyadh during the same period. The results also showed an increase of the PD value in the entire landscape of Jeddah during 2020 (Figure 7B), indicating that there were new and small urban patches that were not connected to the previous patches. It is suggested, therefore, that the urban land in Jeddah is likely to be more fragmented in the future.

Edge density (ED) is another metric that can explain the process of urban expansion. Like PD, there is a pronounced differentiation between both cities. ED reached its peak during 1985 within a radius of five kilometres in Jeddah and then declined as the distance increased from the city centre. Within the same radius, the ED values decreased throughout the period, indicating that urban areas around the city centre fused together between 1985 and 2020. Riyadh, on the other hand, showed a different ED curve. While the ED declined between 1985 and 2020 within the five-kilometre buffer zone, the ED value in 1985 was low compared with Jeddah (Figure 6C). The comparison analysis for the entire boundaries of both cities showed that ED increased in Riyadh between 1985-2014 and declined between 2014-2020, while in Jeddah, the ED declined between 1985-2000 and increased substantially between 2000-2020. These results indicate that the new urban developments after 2014 occurred near existing developments in Riyadh. Thus, the urban patches tend to be more clustered and the landscape is increasingly dominated by urban areas. In contrast, urban areas in Jeddah tend to be dispersed and the urban landscape is mixed with the other land cover types. 

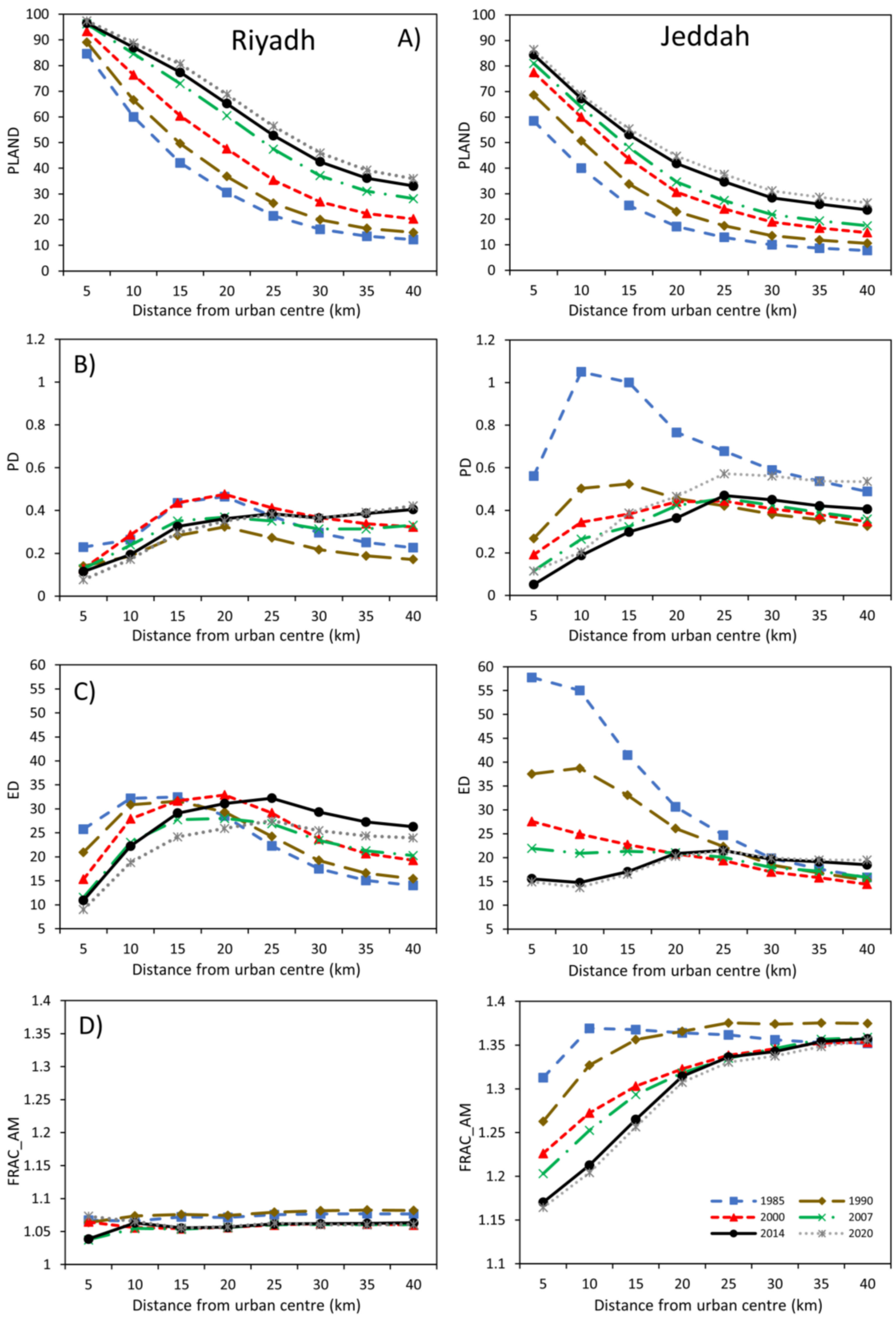

Figure 6. Cont. 

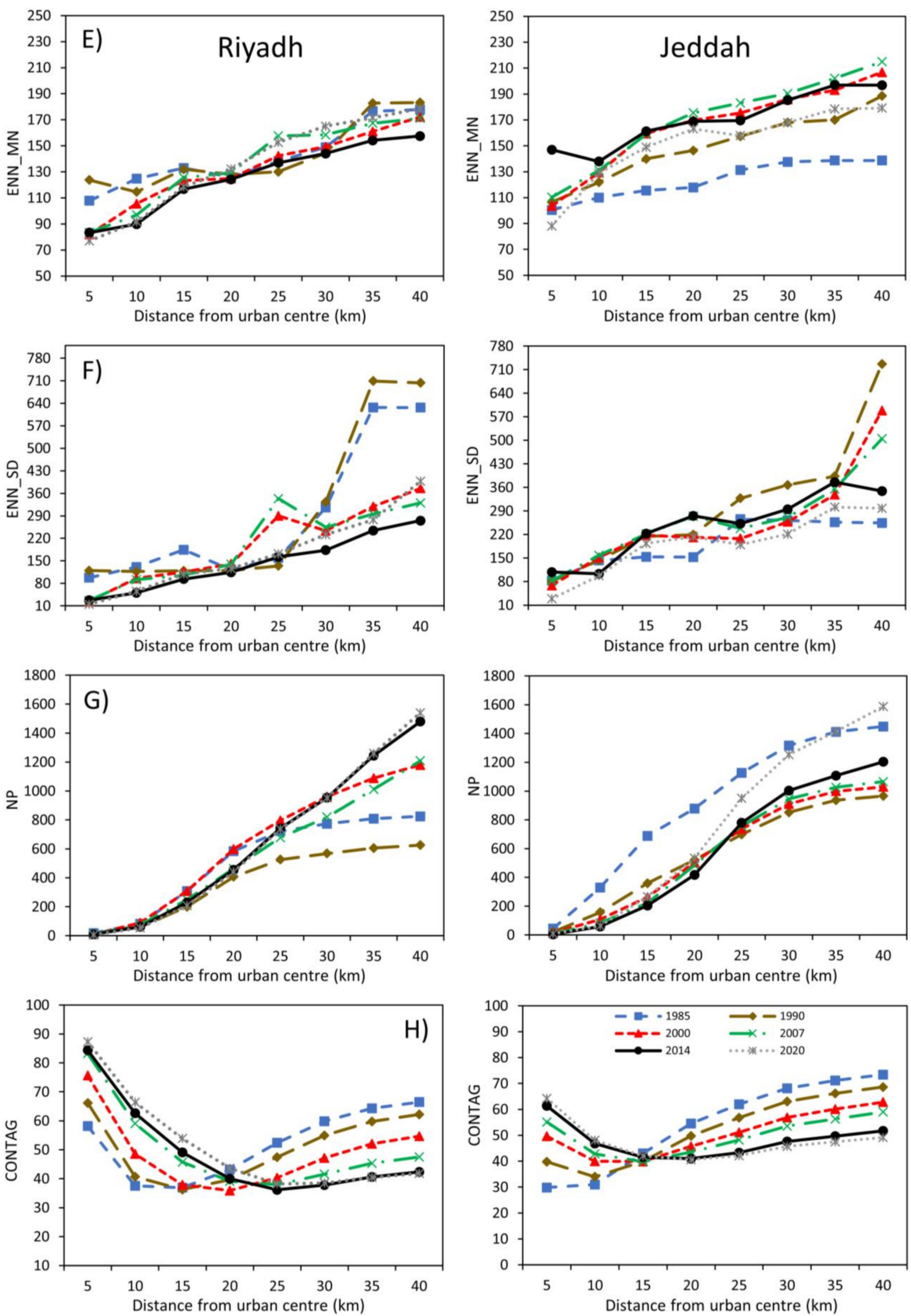

Figure 6. A comparison of landscape metrics between Riyadh and Jeddah across buffer zones: (A) PLAND; (B) PD; (C) ED; (D) FRAC-AM; (E) ENN_EN; (F) ENN_SD; (G) NP; (H) CONTAG. 

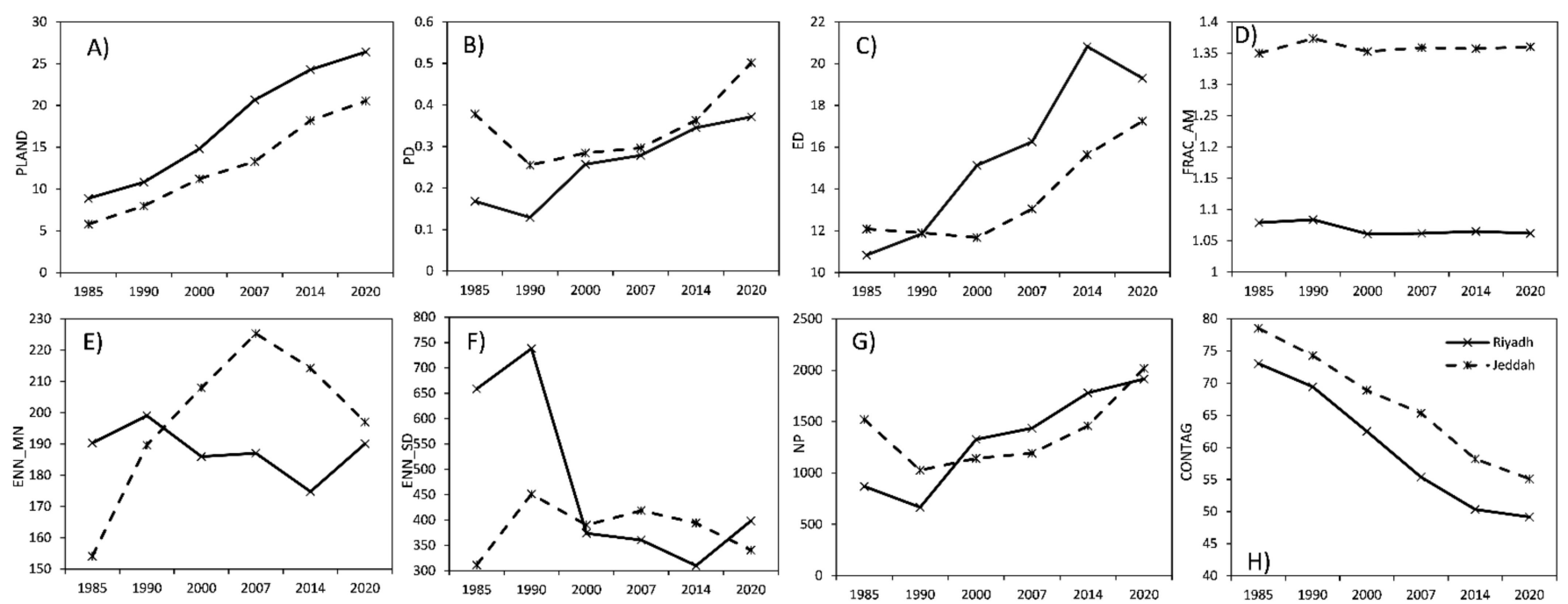

Figure 7. A comparison of landscape metrics between Riyadh and Jeddah for the entire landscape: (A) PLAND; (B) PD; (C) ED; (D) FRAC-AM; (E) ENN_EN; (F) ENN_SD; (G) NP; (H) CONTAG.

The FRAC_AM metric explains the shape of the urban area by which the distribution of urbanization is either a normal or complex process. The FRAC_AM values varied between Jeddah and Riyadh (Figure 6D). Riyadh showed a relatively simple shaped urban form, in which the FRAC_AM values were less than 1.1 for all buffer zones between 1985 and 2020 (Figure 6D). These results indicate that the urban form tended to be more compact and clustered. However, the situation was different in Jeddah. The FRAC_AM was higher for all time periods and the highest value was during 1990 (Figure 7D). Within the five-kilometre buffer zone, the FRAC_AM values decreased throughout the period (Figure 6D), indicating that the urban pattern in the central area moved from the complex form to compactness between 1985 and 2020. The FRAC_AM values are expected to decrease in the central area due to the lack of change in urban cover near the city centre. Nevertheless, the FRAC_AM is likely to increase within the city boundary, resulting in a more complex-shaped and fragmented urban form.

The Euclidean nearest neighbour distance was computed by the mean (ENN_MN) and standard deviation (ENN_SD), and it is presented in Figure 6E,F for each buffer zone and Figure 7E,F for the entire landscape during each time interval. Urban patches in Jeddah in 1985 were relatively aggregated, although the distance increased to its maximum in 2007 by about 225 metres. The distance decreased during the 2014 and 2020 periods. In Riyadh, the ENN_MN curve shows a relatively sine wave shape between 1985 and 2020 (Figure 7E). The highest value was during 1990, by around 200 metres, while the lowest was during 2014 by approximately 175 metres. On the other hand, the ENN_SD diagram shows different results (Figure 7F). Riyadh experienced a high value of ENN_SD during 1985 and 1990, while the values decreased during 2000, 2007 and 2014, and increased by 2020. The different shape between ENN_MN and ENN_SD between the cities indicates that the urban landscape in Jeddah has a dispersed pattern of patches, but it is more regular than Riyadh, which has an irregular landscape but a concentrated pattern of patches.

The contagion index (CONTAG) is shown in Figure $6 \mathrm{H}$ for each buffer zone and Figure $7 \mathrm{H}$ for the entire landscape. The CONTAG values around the central area (5 to $15 \mathrm{~km}$ ) were higher in Riyadh than Jeddah for all time periods, indicating that the area around the urban core was most dispersed and fragmented in Jeddah, while in Riyadh, the central area was more aggregated, especially during 2007, 2014 and 2020. This was found in Jeddah during 1985 and 1990, where the landscape of the city was mostly heterogenous within the central area. In general, the CONTAG values decreased for both cities with a distance from the urban centre to the 20-kilometre buffer in Riyadh and 15-km buffer in Jeddah, and increased as the distance increased, showing a wave-like shape. For the 
entire landscape, Jeddah showed relatively higher CONTAG values than Riyadh, and the CONTAG decreased throughout time in both cities (Figure 7H).

Figure 8A-H shows a comparison of spatial metrics of urban growth in Makkah for multiple buffer zones ( 5 to $20 \mathrm{~km}$ ), and Figure 9 shows the same metrics for the entire landscape during 1985, 1990, 2000, 2007, 2014 and 2020. The percentage of urban landscape increased in Makkah between 1985 and 2020 (Figure 9A). The landscape of the central area (five-kilometre buffer) was covered by urban land use by about $\sim 80 \%$ during the 2014 and 2020 periods (Figure 8A). However, the percentage of urban area decreased with the increase of the distance from the urban core centre. In general, Makkah experienced a high rate of urbanization between 2007 and 2014.

The patch density (PD) also increased between 1985 and 2020 in the entire landscape of Makkah (Figure 9B), as the number of patches (NP) increased during the same time (Figure 9G). Analysis of the buffer zones shows that within the five-kilometre buffer, the PD values were relatively high during 1985-1990 and decreased after that (Figure 8B), indicating that in the early stage of development, the central area was more fragmented and most patchy. During this time the landscape became urbanized around the city centre and the PD values decreased. Additionally, the PD values decreased as the distance increased from the urban core during 1985-1990 and increased between 2000-2020. The 2020 period showed the highest value of PD compared with other periods when the distance increased from the urban centre.

The edge density (ED) values also show a variation in results over space and time (Figures 8C and 9C). Since the urban centre showed higher ED values during 1985, 1990, 2000 and 2007, the ED values decreased during these periods when the distance from the urban core increased. The ED values decreased around the central area and increased for the entire landscape during the 2014 and 2020 periods. These results suggest that the central area was dispersed and mixed with other land cover types during 1985 . The landscape then became more clustered and dominated mostly by urban areas by 2014-2020 as the ED values decreased throughout time.

The area weighted mean patch fractal dimension (FRAC_AM) values are presented for each buffer zone in Figures 8D and 9D for the entire study area. The FRAC_AM values increased between 1990-2000 and continued at nearly the same level between 2000-2007 and decreased between 2007-2014 (Figure 9D). The results of FRAC_AM in Figure 8D show an increase as the distance increases from the urban core after 2000, indicating that the landscape of the city $(>10 \mathrm{~km})$ tended to be a more complex and fragmented urban form. The shape of the central area, however, tended to be at a regular form in recent years (2014 and 2020) as the values become closer to one, which indicates a relatively simple shape.

ENN_MN and ENN_SD are presented in Figure 8E,F for each buffer zone and Figure 9E,F for the entire study area. The 2000 period showed the highest value of the average nearest neighbour and dropped after that time (Figure 9E). This indicates that the 2000 period was the initial phase of diffusion in Makkah as large distances separated new development. For each buffer zone, the ENN_MN values showed an increase as the distance increased from the city centre (Figure 8E), indicating that the urban patches near the core centre are clustered while the patches become isolated as the distance increases from the urban centre. On the other hand, the standard deviation nearest neighbour peaked in 1985 (Figure 9F), which indicates that the distribution of urban patches was irregular across the landscape. However, the SD values decreased after 1985, indicating that the urban patches became uniform across the landscape.

The contagion metric is presented in Figure $8 \mathrm{H}$ for each buffer zone and in Figure $9 \mathrm{H}$ for the entire landscape. The contagion was lowest within the central area (five kilometres), especially during the 1985 and 1990 periods. During this time, the urban configuration was most fragmented around the city centre. Moreover, in 1985-1990, the contagion increased as the distance increased from the urban core, indicating that during 1985-1990, the landscape was homogenised within 15 to $20 \mathrm{~km}$ from the urban centre. In general, contagion decreased 
between 1985 and 2020 for the entire landscape, suggesting that urban patches of Makkah where dispersion occurred in the early years had become more interspersed in recent years.
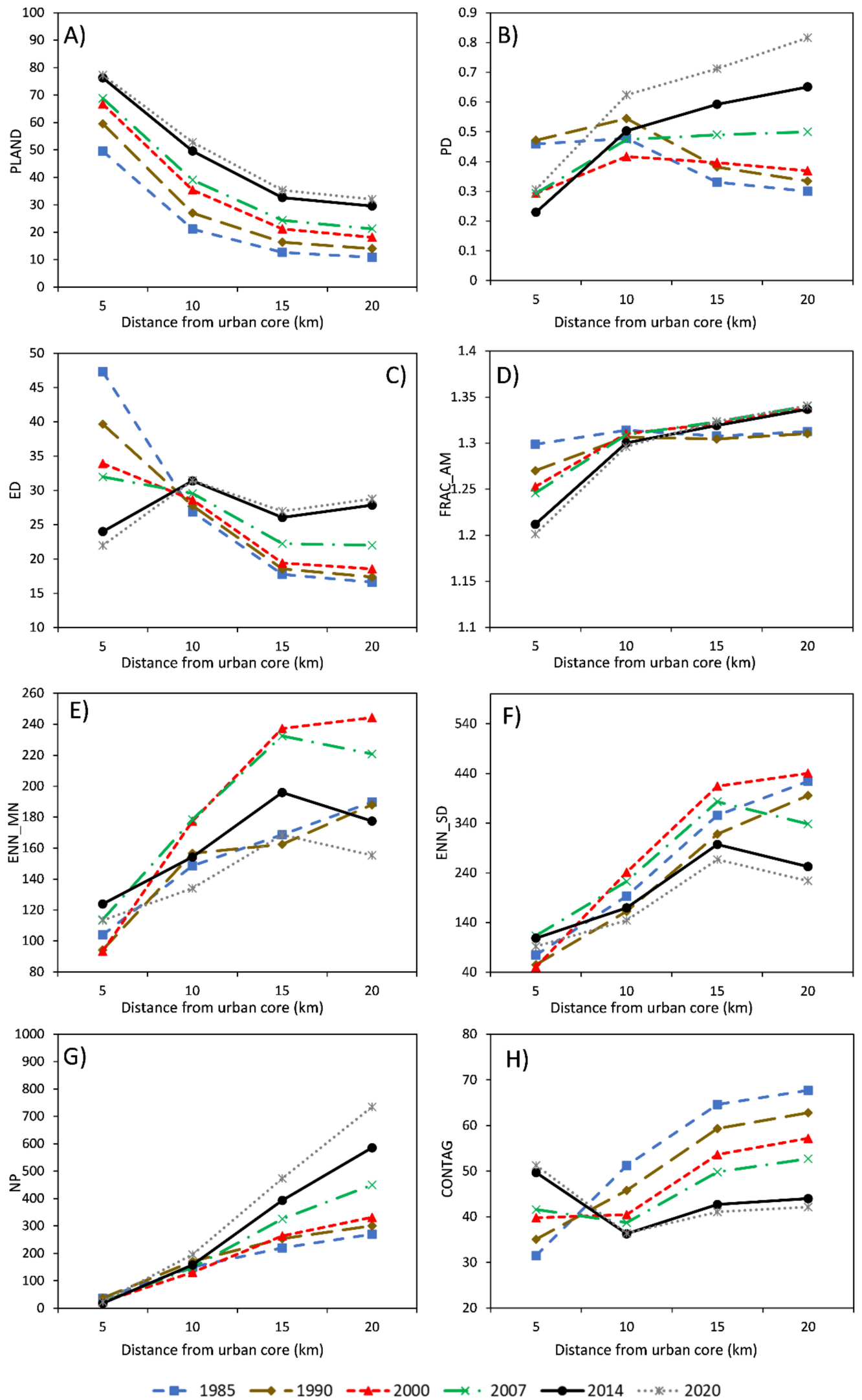

Figure 8. Landscape metrics of urban growth in Makkah across buffer zones: (A) PLAND; (B) PD; (C) ED; (D) FRAC-AM; (E) ENN_EN; (F) ENN_SD; (G) NP; (H) CONTAG. 

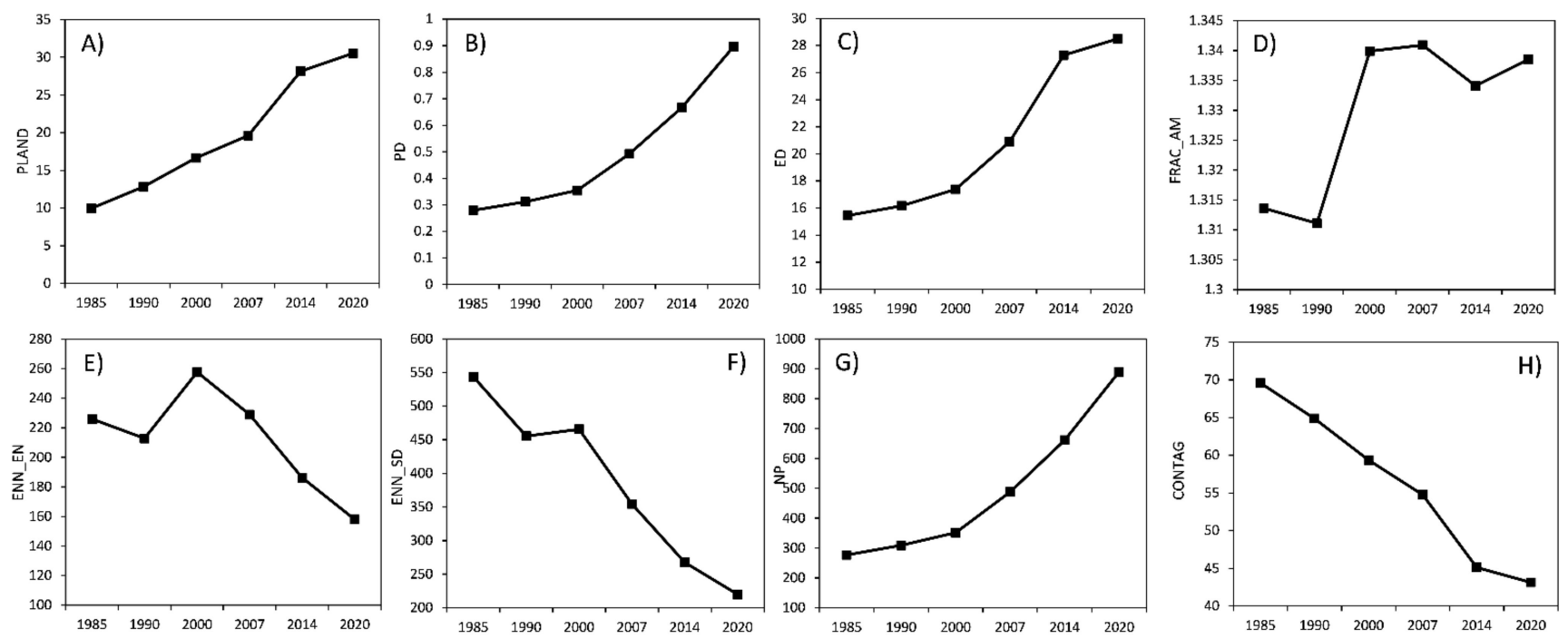

Figure 9. Landscape metrics of urban growth in Makkah for the entire landscape:

(A) PLAND;

(B) $\mathrm{PD}$; (C) ED;

(D) FRAC-AM; (E) ENN_EN; (F) ENN_SD; (G) NP; (H) CONTAG.

\section{Discussion}

The change detection results showed that all three cities were significantly changed between 1985 and 2020. However, the amount of change during each period varied from city to city. Most of the expansion in Riyadh occurred between 2000-2007, while the expansion in Jeddah and Makkah occurred between 1990-2000 and 2007-2014, respectively. The massive urban growth can be attributed to several factors. First, the government policy that was implemented during the last 40 years. The benefits provided by these cities for the economy of the country encouraged the government to direct development towards these cities. The second factor was the increase in migration towards the three cities. The features that are specific to each city make them attractive to those seeking a better life. Jeddah, for example, has long been recognised as a major commercial centre in Saudi Arabia [51], while in recent years Riyadh has become home to $34 \%$ of the production industry of the country [52]. Makkah is also witnessing growth in tourism due to the increasing number of pilgrims. These factors have resulted in a steady rise in migration to these cities that has mainly contributed to the urban expansion.

The shape of urban area can be identified through landscape metrics such as the area weighted mean patch fractal dimension. This metric can measure the degree of complexity and is accepted by researchers because it is normalised [4]. The results indicated that the urban form in Riyadh was relatively simple, while the urban area in Jeddah tended to be more complex and showed irregular form. This is likely due to two reasons. The first relates to the biophysical constraints (e.g., elevation and water) for each city. Vacant lands that are close to the urban areas are relatively flat in Riyadh, especially in the eastern, northern and western parts. These flat areas promote the growth of the city to occur at the edge of the existing development. In contrast, the elevated area in the eastern part of Jeddah and the coastal line in the western part force development to occur at the northern and southern sectors, where it is suitable for new construction. While urban growth was observed in the eastern part of the city, the urban patches were disconnected and separated from the main urban area, which is probably due to the topographic structure. The second reason may be attributed to socioeconomic characteristics. The city centre in Riyadh contains many government buildings, services and commercial agencies [53]. This allowed the expansion to start from the city centre and expand towards the outskirts, which indicates a circular or square expansion [54]. Unlike Riyadh, the city centre of Jeddah is less important, as most of the services and commercial agencies are decentralised. 
Makkah, in contrast, has a different urban shape. Although urban growth was relatively simple in its early development during 1985 and 1990, the expansion of the urban area tended to be more complex from 2000 to 2020. In the early stage of development, urban areas were scattered around the city centre, which is the area of and around the Grand Mosque. In the past, that area contained almost all the commercial centres and needs for residents, which attracted people to live there. In addition to the commercial advantages, residents also chose to live around the city centre for religious purposes. In the 1980s, the government started to encourage residents and private sectors to evacuate the central area to accommodate pilgrims and visitors to holy places. The government provided financial compensation to the owners to leave their homes and businesses. This resulted in increased urbanization on the margins of the city. The recent urban growth was distributed mostly in the eastern, north-eastern and northern sectors. However, urban patches in these parts were disconnected due to the topographic constraints, which has mainly resulted in a complex urban form in the city.

The spatial structure of the three cities changed quickly between 1985 and 2020. The change has mostly occurred in the periphery areas (greater than $20 \mathrm{~km}$ ) of the selected cities that have developed rapidly in recent years. This is probably due to a change in the socioeconomic environment of the country. In the past, the structure of Saudi Arabian cities was in complete contrast with most cities in the western world. High-class residential developments were located in the central area [55] while the low-class residential areas occupied the peripheries. However, the western model has been applied in recent years, with the high-class residential areas locating to the peripheries. This has changed the periphery areas with the demand for high-quality residential developments in those areas.

The pattern of urban growth in the three cities has varied over time. The urban pattern in 1985 in Riyadh was relatively dispersed, especially on the fringes, but this has changed over time to an aggregated pattern. In the early development, urban growth occurred near road networks, but it was not close to the existing development. Later, urban areas were fused together in the city and have become less fragmented in recent years. The urban pattern in Makkah tends to be more fragmented. This is probably due to the natural topography that could inhibit growth to connect it to the other urban areas. New construction occurs wherever available and suitable vacant land can be found. Jeddah has shown a dispersed urban growth: the landscape of the city contains small urban patches that are not connected to other urban areas. The results indicate a lack of urban planning in the city.

While the rate of urban growth decreased between 2014 and 2020 in the three cities compared with other periods, urbanization is expected to increase in the future. The government is currently working to raise the economy of the country through reliance on the investment, tourism and industrial sectors. Major cities will be the target of these sectors due to the demand for the required infrastructure. Although accelerated urbanization is not necessarily aimed at achieving the anticipated economic growth [56], the government will continue to increase the rate of urbanization during the next few years to promote growth in the economy, especially in Jeddah and Riyadh. The expected expansion will require an effective planning policy that can manage the existing growth while simultaneously considering its impact on the natural environment.

Indeed, Saudi Arabia regularly undergoes a variety of environmental changes caused by its harsh environment, such as drought, water shortages and wind erosion [57]. Anthropogenic activity is known to cause more profound changes than natural phenomena and increase the stress on this sensitive environment $[14,58]$. Such developments have resulted in unprecedented changes and alterations to various components of the environment, such as hydrological processes, climatic systems, landscape ecology and various aspects of land cover patterns. Information regarding urban growth and its impact is urgently required to understand its spatial and temporal patterns, together with its spatial extent. This data could assist planners and ecologists in developing an appropriate and sustainable management strategy that might mitigate future impacts on the environment. 
An analysis of urban land use patterns using landscape metrics could be conducted through a variety of procedures. As previous studies have implemented landscape metrics on whole urban boundaries $[28,59]$ or along transects $[60,61]$, the concentric rings procedure can track the changes in an urban area based on the distance from the core centre. Furthermore, it could localise the urban patterns not only in the developed urban areas, but also in the developing areas on the outskirts of cities. Studies that conducted landscape metrics using concentric rings could distinguish changes and patterns on the fringes of urban areas. For example, Seto and Fragkias [4] emphasised that the concentric rings capture development processes from the urban centre of various urban-rural areas. Ranagalage et al. [62] applied a gradient analysis using concentric rings around the urban core centre to capture the spatial distribution dynamics of land use and cover from the city centre to the rural areas. This is emphasised also in this research, in which the analysis of the concentric rings showed the urban patterns for each buffer during each period, including the outskirts.

\section{Conclusions}

Integrating remote sensing data and landscape metrics has proven to be useful in identifying urban growth patterns and processes. Remote sensing data can detect and track urban changes through space and time. Additionally, landscape metrics can determine the spatial configuration of urban areas. This research used satellite images and landscape metrics to identify urban growth patterns and processes in three of the most expanding cities in Saudi Arabia-Riyadh, Jeddah and Makkah-between 1985 and 2020. The spatiotemporal results indicate that all three cities experienced significant urban expansion during this time. Government policy has contributed significantly to the increase in urbanization by directing development to these cities for economic benefits. Regarding urban patterns and processes, the results indicate that Makkah and Jeddah showed a complex urban form, while urban growth in Riyadh was relatively simple. The spatial patterns of each city also varied among the three cities. Although urban pattern was relatively dispersed in the early stage of development during 1985 in Riyadh, the pattern changed to become more aggregated in recent years. The urban pattern in Jeddah was dispersed, while in Makkah, the urban pattern was fragmented. Urbanization is likely to increase in these cities in the future as the government attempts to reduce its dependency on oil and increase investment in the major cities by elevating the service industry.

This study provides essential information regarding the trajectory of urban growth in Saudi Arabian cities over the past four decades. This information is vital in providing an understanding of urban change patterns and to support the decision-making processes of planners and local authorities in the three cities. The quantification of urban change is also crucial for various ecological and environmental studies.

While the methods used in this research could identify the spatial configuration of urban growth in the three cities, incorporating socioeconomic and biophysical factors-such as population density, elevation and slope-into the statistical analysis could explain the reasons for the spatial pattern and shape of urban growth in each city. It is important to understand the causal factors that create an urban pattern within cities to facilitate better urban planning and to ensure sustainable development.

Funding: This research received no external funding.

Institutional Review Board Statement: Not applicable.

Informed Consent Statement: Not applicable.

Data Availability Statement: Not applicable.

Conflicts of Interest: The author declares no conflict of interest. 


\section{References}

1. Zhou, X.; Chen, H. Impact of urbanization-related land use land cover changes and urban morphology changes on the urban heat island phenomenon. Sci. Total Environ. 2018, 635, 1467-1476. [CrossRef]

2. Hou, L.; Wu, F.; Xie, X. The spatial characteristics and relationships between landscape pattern and ecosystem service value along an urban-rural gradient in Xi'an city, China. Ecol. Indic. 2020, 108, 105720. [CrossRef]

3. United Nations. World Population Prospects 2019. Department of Economic and Social Affairs Population Division; United Nations: New York, NY, USA, 2019.

4. Seto, K.C.; Fragkias, M. Quantifying Spatiotemporal Patterns of Urban Land-use Change in Four Cities of China with Time Series Landscape Metrics. Landsc. Ecol. 2005, 20, 871-888. [CrossRef]

5. Zhang, X.Q. The Economic Role of Cities; UN-HABITAT: Nairobi, Kenya, 2011.

6. Grimm, N.B.; Faeth, S.H.; Golubiewski, N.E.; Redman, C.L.; Wu, J.; Bai, X.; Briggs, J.M. Global Change and the Ecology of Cities. Science 2008, 319, 756-760. [CrossRef] [PubMed]

7. Alberti, M. The Effects of Urban Patterns on Ecosystem Function. Int. Reg. Sci. Rev. 2005, 28, 168-192. [CrossRef]

8. Liu, Z.; He, C.; Wu, J. General Spatiotemporal Patterns of Urbanization: An Examination of 16 World Cities. Sustainability 2016, 8 , 41. [CrossRef]

9. Alberti, M.; Palkovacs, E.P.; Roches, S.D.; Meester, L.D.; Brans, K.I.; Govaert, L.; Grimm, N.B.; Harris, N.C.; Hendry, A.P.; Schell, C.J.; et al. The Complexity of Urban Eco-evolutionary Dynamics. BioScience 2020, 70, 772-793. [CrossRef]

10. Zhou, Y.; Smith, S.J.; Zhao, K.; Imhoff, M.; Thomson, A.; Bond-Lamberty, B.; Asrar, G.R.; Zhang, X.Q.; He, C.; Elvidge, C.D. A global map of urban extent from nightlights. Environ. Res. Lett. 2015, 10, 054011. [CrossRef]

11. Li, X.; Zhou, W.; Ouyang, Z. Forty years of urban expansion in Beijing: What is the relative importance of physical, socioeconomic, and neighborhood factors? Appl. Geogr. 2013, 38, 1-10. [CrossRef]

12. Arribas-Bel, D.; Sanz-Gracia, F. The validity of the monocentric city model in a polycentric age: US metropolitan areas in 1990, 2000 and 2010. Urban Geogr. 2014, 35, 980-997. [CrossRef]

13. Mubarak, F.A. Urban growth boundary policy and residential suburbanization: Riyadh, Saudi Arabia. Habitat Int. 2004, 28, 567-591. [CrossRef]

14. Alqurashi, A.F.; Kumar, L. Land use and land cover change detection in the Saudi Arabian desert cities of Makkah and Al-Taif using satellite data. Adv. Remote Sens. 2014, 3, 106-119. [CrossRef]

15. Al-Hathloul, S.; Mughal, M.A. Urban growth management-the Saudi experience. Habitat Int. 2004, 28, 609-623. [CrossRef]

16. Gamboa, J. City Expanding to The Desert Horizon: Riyadh's problem of explosive growth and urban sprawl. Geography 2008, 554, 7-14.

17. Alqurashi, A.F.; Kumar, L. Spatiotemporal patterns of urban change and associated environmental impacts in five Saudi Arabian cities: A case study using remote sensing data. Habitat Int. 2016, 58, 75-88. [CrossRef]

18. Chen, J.; Chen, J.; Liao, A.; Cao, X.; Chen, L.; Chen, X.; He, C.; Han, G.; Peng, S.; Lu, M.; et al. Global land cover mapping at 30m resolution: A POK-based operational approach. ISPRS J. Photogramm. Remote Sens. 2015, 103, 7-27. [CrossRef]

19. Toure, S.I.; Stow, D.A.; Shih, H.; Weeks, J.; Lopez-Carr, D. Land cover and land use change analysis using multi-spatial resolution data and object-based image analysis. Remote Sens. Environ. 2018, 210, 259-268. [CrossRef]

20. Roy, D.P.; Wulder, M.A.; Loveland, T.R.; Woodcock, C.E.; Allen, R.G.; Anderson, M.C.; Helder, D.; Irons, J.R.; Johnson, D.M.; Kennedy, R.; et al. Landsat-8: Science and product vision for terrestrial global change research. Remote Sens. Environ. 2014, 145, 154-172. [CrossRef]

21. Goldblatt, R.; Stuhlmacher, M.F.; Tellman, B.; Clinton, N.; Hanson, G.; Georgescu, M.; Wang, C.; Serrano-Candela, F.; Khandelwal, A.K.; Cheng, W.; et al. Using Landsat and nighttime lights for supervised pixel-based image classification of urban land cover. Remote Sens. Environ. 2018, 205, 253-275. [CrossRef]

22. Sinha, P.; Verma, N.K.; Ayele, E. Urban built-up area extraction and change detection of Adama Municipal area using time-series Landsat images. Int. J. Adv. Remote Sens. GIS 2016, 5, 1886-1895. [CrossRef]

23. Deliry, S.I.; Avdan, Z.Y.; Avdan, U. Extracting urban impervious surfaces from Sentinel-2 and Landsat-8 satellite data for urban planning and environmental management. Environ. Sci. Pollut. Res. 2021, 28, 6572-6586. [CrossRef]

24. Zhang, C.; Sargent, I.; Pan, X.; Li, H.; Gardiner, A.; Hare, J.; Atkinson, P.M. An object-based convolutional neural network (OCNN) for urban land use classification. Remote Sens. Environ. 2018, 216, 57-70. [CrossRef]

25. Myint, S.W.; Gober, P.; Brazel, A.; Grossman-Clarke, S.; Weng, Q. Per-pixel vs. object-based classification of urban land cover extraction using high spatial resolution imagery. Remote Sens. Environ. 2011, 115, 1145-1161. [CrossRef]

26. Yu, W.; Zhou, W.; Qian, Y.; Yan, J. A new approach for land cover classification and change analysis: Integrating backdating and an object-based method. Remote Sens. Environ. 2016, 177, 37-47. [CrossRef]

27. Frankhauser, P. Fractal geometry for measuring and modelling urban patterns. In The Dynamics of Complex Urban Systems: An Interdisciplinary Approach; Albeverio, S., Andrey, D., Giordano, P., Vancheri, A., Eds.; Physica-Verlag HD: Heidelberg, Germany, 2008; pp. 213-243.

28. Aguilera, F.; Valenzuela, L.M.; Botequilha-Leitão, A. Landscape metrics in the analysis of urban land use patterns: A case study in a Spanish metropolitan area. Landsc. Urban Plan. 2011, 99, 226-238. [CrossRef]

29. O'Neill, R.V.; Krummel, J.R.; Gardner, R.H.; Sugihara, G.; Jackson, B.; DeAngelis, D.L.; Milne, B.T.; Turner, M.G.; Zygmunt, B.; Christensen, S.W.; et al. Indices of landscape pattern. Landsc. Ecol. 1988, 1, 153-162. [CrossRef] 
30. McGarigal, K. Landscape Pattern Metrics; Wiley StatsRef; Statistics Reference Online: New York, NY, USA, 2014.

31. Schneider, A.; Woodcock, C.E. Compact, Dispersed, Fragmented, Extensive? A comparison of urban growth in twenty-five global cities using remotely sensed data, pattern metrics and census information. Urban Stud. 2008, 45, 659-692. [CrossRef]

32. Dietzel, C.; Herold, M.; Hemphill, J.J.; Clarke, K.C. Spatio-temporal dynamics in California's Central Valley: Empirical links to urban theory. Int. J. Geogr. Inf. Sci. 2005, 19, 175-195. [CrossRef]

33. Alahmadi, M.; Atkinson, P.M. Three-fold urban expansion in Saudi Arabia from 1992 to 2013 observed using calibrated DMSP-OLS night-time lights imagery. Remote Sens. 2019, 11, 2266. [CrossRef]

34. Alahmadi, M.; Mansour, S.; Martin, D.; Atkinson, P.M. An improved index for urban population distribution mapping based on nighttime lights (DMSP-OLS) data: An experiment in Riyadh Province, Saudi Arabia. Remote Sens. 2021, 13, 1171. [CrossRef]

35. Aljoufie, M.; Zuidgeest, M.; Brussel, M.; van Maarseveen, M. Spatial-temporal analysis of urban growth and transportation in Jeddah City, Saudi Arabia. Cities 2013, 31, 57-68. [CrossRef]

36. Rahman, M.T. Detection of land use/land cover changes and urban sprawl in Al-Khobar, Saudi Arabia: An analysis of multitemporal remote sensing data. ISPRS Int. J. Geo-Inf. 2016, 5, 15. [CrossRef]

37. Alqurashi, A.F.; Kumar, L.; Sinha, P. Urban land cover change modelling using time-series satellite images: A case study of urban growth in five cities of Saudi Arabia. Remote Sens. 2016, 8, 838. [CrossRef]

38. Wardak, A. Crime and social control in Saudi Arabia. In Transnational and Comparative Criminology; Routledge-Cavendish: London, UK, 2005; pp. 91-116.

39. Benz, U.C.; Hofmann, P.; Willhauck, G.; Lingenfelder, I.; Heynen, M. Multi-resolution, object-oriented fuzzy analysis of remote sensing data for GIS-ready information. ISPRS J. Photogramm. Remote Sens. 2004, 58, 239-258. [CrossRef]

40. Drăguţ, L.; Tiede, D.; Levick, S.R. ESP: A tool to estimate scale parameter for multiresolution image segmentation of remotely sensed data. Int. J. Geogr. Inf. Sci. 2010, 24, 859-871. [CrossRef]

41. Taubenböck, H.; Esch, T.; Felbier, A.; Wiesner, M.; Roth, A.; Dech, S. Monitoring urbanization in mega cities from space. Remote Sens. Environ. 2012, 117, 162-176. [CrossRef]

42. Zhou, W.; Troy, A. An object-oriented approach for analysing and characterizing urban landscape at the parcel level. Int. J. Remote Sens. 2008, 29, 3119-3135. [CrossRef]

43. Zhou, W.; Troy, A.; Grove, M. Object-based land cover classification and change analysis in the Baltimore Metropolitan Area using multitemporal high resolution remote sensing data. Sensors 2008, 8, 1613-1636. [CrossRef]

44. Alqurashi, A.F.; Kumar, L. An assessment of the impact of urbanization and land use changes in the fast-growing cities of Saudi Arabia. Geocarto Int. 2017, 34, 78-97. [CrossRef]

45. McGarigal, K.; Cushman, S.A.; Neel, M.; Ene, E. FRAGSTATS: Spatial Pattern Analysis Program for Categorical Maps. Computer Software Program Produced by the Authors at the University of Massachusetts, Amherst. 2002. Available online: http: //www.umass.edu/landeco/research/fragstats/fragstats (accessed on 18 January 2021).

46. Cabral, A.I.R.; Costa, F.L. Land cover changes and landscape pattern dynamics in Senegal and Guinea Bissau borderland. Appl. Geogr. 2017, 82, 115-128. [CrossRef]

47. Yu, Z.; Wang, Y.; Deng, J.; Shen, Z.; Wang, K.; Zhu, J.; Gan, M. Dynamics of hierarchical urban green space patches and implications for management policy. Sensors 2017, 17, 1304. [CrossRef] [PubMed]

48. Liu, S.; Zhang, X.Q.; Feng, Y.; Xie, H.; Jiang, L.; Lei, Z. Spatiotemporal dynamics of urban green space influenced by rapid urbanization and land use policies in Shanghai. Forests 2021, 12, 476. [CrossRef]

49. Abubakar, G.A.; Wu, J.; Shahtahmassebi, A.R.; Wang, K. Necessity of a multifaceted approach in analyzing growth of impervious surfaces. Sustainability 2020, 12, 4109. [CrossRef]

50. Hesselbarth, M.H.K.; Sciaini, M.; With, K.A.; Wiegand, K.; Nowosad, J. landscapemetrics: An open-source R tool to calculate landscape metrics. Ecography 2019, 42, 1648-1657. [CrossRef]

51. Mandeli, K. Public space and the challenge of urban transformation in cities of emerging economies: Jeddah case study. Cities 2019, 95, 102409. [CrossRef]

52. Alsaud, A.B.; Yas, H.; Alatawi, A. A new decision-making approach for Riyadh makes up 50 percent of the non-oil economy of Saudi Arabia. J. Contemp. Issues Bus. Gov. 2021, 27, 3376-3392.

53. Altuwaijri, H.A.; Alotaibi, M.H.; Almudlaj, A.M.; Almalki, F.M. Predicting urban growth of Arriyadh city, capital of the Kingdom of Saudi Arabia, using Markov cellular automata in TerrSet geospatial system. Arab. J. Geosci. 2019, 12, 135. [CrossRef]

54. Boulila, W.; Ghandorh, H.; Khan, M.A.; Ahmed, F.; Ahmad, J. A novel CNN-LSTM-based approach to predict urban expansion. Ecol. Inform. 2021, 64, 101325. [CrossRef]

55. Malik, S.A. Rural Migration and Urban Growth in Riyadh, Saudi Arabia; University of Michigan: Ann Arbor, MI, USA, 1973.

56. Chen, M.; Zhang, H.; Liu, W.; Zhang, W. The global pattern of urbanization and economic growth: Evidence from the last three decades. PLoS ONE 2014, 9, e103799. [CrossRef]

57. Vincent, P. Saudi Arabia: An Environmental Overview; CRC Press: London, UK, 2008.

58. Rahman, M.T.; Aldosary, A.S.; Mortoja, M.G. Modeling future land cover changes and their effects on the land surface temperatures in the Saudi Arabian Eastern Coastal City of Dammam. Land 2017, 6, 36. [CrossRef]

59. Xu, C.; Liu, M.; Zhang, C.; An, S.; Yu, W.; Chen, J.M. The spatiotemporal dynamics of rapid urban growth in the Nanjing metropolitan region of China. Landsc. Ecol. 2007, 22, 925-937. [CrossRef] 
60. Li, J.; Li, C.; Zhu, F.; Song, C.; Wu, J. Spatiotemporal pattern of urbanization in Shanghai, China between 1989 and 2005. Landsc. Ecol. 2013, 28, 1545-1565. [CrossRef]

61. Li, S.; Liu, X.; Li, Z.; Wu, Z.; Yan, Z.; Chen, Y.; Gao, F. Spatial and temporal dynamics of urban expansion along the GuangzhouFoshan inter-city rail transit corridor, China. Sustainability 2018, 10, 593. [CrossRef]

62. Ranagalage, M.; Morimoto, T.; Simwanda, M.; Murayama, Y. Spatial analysis of urbanization patterns in four rapidly growing south Asian cities using Sentinel-2 Data. Remote Sens. 2021, 13, 1531. [CrossRef] 